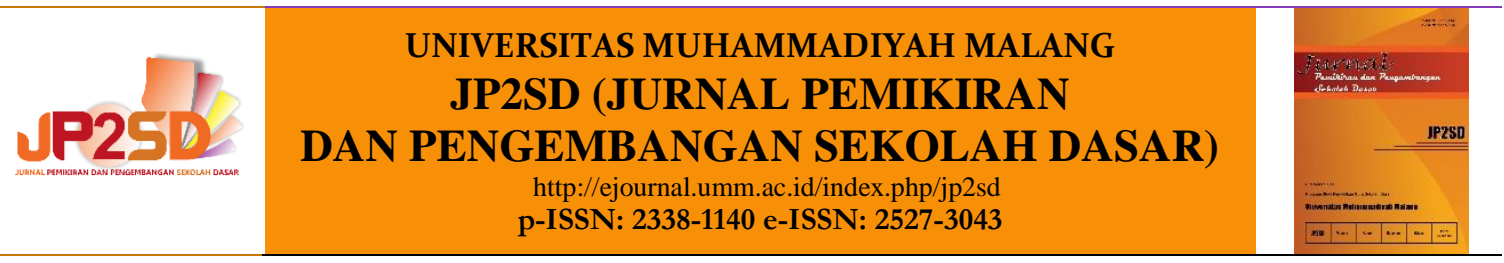

\title{
Penerapan Media Game Ular Tangga Digital untuk Meningkatkan Hasil Belajar Tematik
}

\author{
Lina Novita ${ }^{\text {a1* }}$, Fitri Siti Sundari ${ }^{\text {a2 }}$, Khansa Rohadatul'Aisy Rabani ${ }^{\text {a3 }}$ \\ aPendidikan Guru Sekolah Dasar, Universitas Pakuan, Indonesia \\ ${ }^{1}$ linovtaz@gmail.com, ${ }^{2}$ fitri.siti.sundari@ unpak.ac.id, ${ }^{3}$ khsrabbani@gmail.com \\ *Penulis Korespondensi
}

\section{INFORMASI ARTIKEL \\ Riwayat: \\ Diterima 30 Mei 2020 \\ Revisi 11 Juli 2020 \\ Dipublikasikan 20 September \\ 2020}

Kata kunci:

Ular tangga digital, hasilbelajar,

Sekolah Dasar

\begin{abstract}
ABSTRAK
Penelitian ini bertujuan untuk meningkatkan hasil belajar dan menumbuhkan keaktifan siswa dengan penggunaan media ular tangga digital. Metode penelitian tindakan kelas digunakan dalam penelitian ini. Subjek penelitian siswa kelas IV berjumlah 35 siswa. Penelitian ini dilakukan dengan 2 siklus, yang terdiri dari perencanaan, pelaksanaan, pengamatan, dan refleksi. Siklus 2 dilakukan, apabila pada siklus 1 belum mencapai indikator keberhasilan pembelajaran. Pengumpulan data dan analisis data dilakukan dari hasil pelaksanaan pembelajaran dan observasi yang dilakukan kolaborator. Hasil penelitian menunjukkan adanya peningkatan hasil belajar dan perubahan sikap dengan penggunaan media game ular tangga digital. Peningkatan tersebut dibuktikan dengan angka rata-rata siklus 1 , yaitu 74,42 meningkat menjadi 84,02 pada siklus 2 , artinya terjadi peningkatan 9,6. Dengan demikian dapat disimpulkan bahwa media ular tangga digital dapat meningkatkan hasil belajar dan adanya perubahan aktivitas siswa pada proses pembelajaran. Hal ini dapat dikatakan bahwa pembelajaran dengan menggunakan media baik itu ular tangga digital maupun media pembelajaran lainnya dapat mengubah pembelajaran menjadi lebih aktif.
\end{abstract}

\section{ABSTRACT}

Keywords:

Snake digital ladder, learning result, elementary school

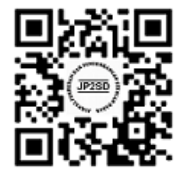

Copyright (C) 2020, Lina
This study aims to improve learning outcomes and foster student activity with the use of digital ladder snake media. Classroom action research methods were used in this study. The research subjects of the fourth grade students were 35 students. This research was conducted in 2 cycles, consisting of planning, implementing, observing, and reflecting. Cycle 2 is carried out, if cycle 1 has not reached the indicators of learning success. Data collection and data analysis were carried out from the results of the implementation of learning and observations made by collaborators. The results showed 


\section{Novita, Fitri Siti Sundari, \\ Khansa Rohadatul'Aisy \\ Rabani}

This is an open access article under the CC-BY-SA license an increase in learning outcomes and changes in attitudes with the use of the digital snake and ladder game media. This increase is evidenced by the average number of cycle 1 , namely 74.42 , increasing to 84.02 in cycle 2 , which means an increase of 9.6. Thus it can be concluded that the digital snake and ladder media can improve learning outcomes and change student activities in the learning process. It can be said that learning using media, both digital ladders and other learning media, can transform learning to be more active.

How to cite: Lina Novita, Fitri Siti Sundari, Khansa Rohadatul'Aisy Rabani. (2020). Penerapan Media Game Ular Tangga Digital untuk Meningkatkan Hasil Belajar Tematik. Jurnal Pemikiran dan Pengembangan Sekolah Dasar, Vol 8 No 2, 126-137. doi: https://doi.org/10.22219/jp2sd.v8i2.12329

\section{PENDAHULUAN}

Kualitas pembelajaran ditentukan oleh interaksi antara guru dan siswa. Interaksi yang terjalin dapat dilakukan dengan kegiatan belajar yang mengaktifkan siswa di dalam kelas. Namun, berdasarkan hasil obeservasi diketahui guru masih mendominasi pembelajaran. Kondisi ini sesuai dengan permasalahan dalam penelitian yang telah dilakukan (Karo-Karo \& Rohani, 2018) bahwa guru masih memiliki konsep memberikan informasi sebanyak-banyaknya, sehingga terjadi praktik induktrinasi yang berdampak pada penghambatan kreativitas siswa. Kondisi tersebut dapat menyebabkan rendahnya hasil belajar siswa, seperti dalam penelitian-penelitian yang telah dilakukan (O'Connor et al., 2011), (Alial-Sahel, 2005), (Delcourt et al., 2007), (Gillies \& Ashman, 2000), (Okada \& Matsuda, 2019).

Peran guru dalam pembelajaran bukan saja pemberi informasi kepada siswa. Guru harus memiliki kreativitas dan inovasi untuk menciptakan kelas yang aktif. Kenyataan tersebut sejalan dengan konsep pembelajaran pada kurikulum 2013. Kreativitas dan inovasi guru diperlukan untuk memotivasi belajar siswa. Guru dapat berinovasi dalam hal media pembelajaran. Perkembangan teknologi dapat dimaknai dengan inovasi oleh guru. sejalan dengan hal tersebut (Hidayati \& Wuryandari, 2012), (Wang \& Lin, 2020), (Law \& Stock, 2019)(Schneider et al., 2018) menekankan pentingnya media yang berbasis teknologi. Demikian juga dengan temuan hasil penelitian (Novita et al., n.d.) 2020) tentang pemanfaatan media berbasis TIK yang masih rendah di lingkungan sekolah dasar.

Penggunaan media dirasakan perlu dalam pencapaian tujuan pembelajaran. Keberhasilan suatu pembelajaran selain ditentukan oleh penerapan model pembelajaran juga ditentukan oleh penggunaan media pembelajaran. Guru yang kreatif dan inovatif dapat memanfaatkan dan menggunakan media sesuai dengan materi yang akan dibelajarkan. Penggunaan media pembelajaran dapat mengurangi unsur verbalisme yang terjadi. Dengan penggunaan media konsep-konsep yang abstrak dapat dipahami secara kongkret oleh siswa. Penggunaan media pembelajaran akan dapat terealisasi dengan adanya kemajuan teknologi, sehingga mempermudah untuk meningkatkan kualitas pembelajaran. Media pembelajaran seperti permainan atau game dapat memotivasi siswa dalam belajar (Bawa et al., 2018), (Martin et al., 2019). Penggunaan media pembelajaran selain media ular tangga digital telah menarik perhatian (Novita et al., n.d.)(2019) (Kuncahyono, 2018) dengan temuan bahwa media pembelajaran dapat meningkatkan keaktifan, kerjasama, dan kedisiplinan siswa dalam proses pembelajaran. 
Kemudian penelitian dengan media ular tangga telah menarik perhatian peneliti lain, diantaranya (Dewi et al., 2017) dengan metodologi penelitian tindakan kelas. Hasil penelitian menyatakan bahwa penggunaan media permainan ular tangga meningkatkan hasil belajar. Selanjutnya penelitian (Afandi, 2015) yang mengembangkan media pembelajaran permainan ular tangga dalam pembelajaran Ilmu Pengetahuan Sosial (IPS) di sekolah dasar. Pengembangan penelitian mengadopsi model 4D dari model Thiagarajan, dkk. yaitu define, design, develop, dan dissaminate. Teknik pengumpulan data dalam penelitian melalui observasi, pemberian angket, dan tes. Pentingnya media berbasis digital juga diteliti oleh (Efendi, 2018)(Efendi, 2018) yang mendeskripsikan penggunaan animasi digital sebagai metode pembelajaran siswa belajar aktif dalam revolusi pembelajaran berbasis digital. Selanjutnya (Syawaluddin et al., 2020), bahwa media ular tangga merupakan media yang dapat meningkatkan minat dan hasil belajar.

Penelitian terdahulu di atas menarik peneliti untuk melakukan penelitian lanjutan di SDN Pengadilan 2 Kota Bogor. Penelitian yang akan dilakukan ini memiliki urgensi pada peningkatan hasil belajar terutama pada pembelajaran kurikulum 2013 yang lebih menekankan pada penguasaan materi dengan tema pada setiap muatan pelajaran. Dalam hal ini materi pada muatan pelajaran terkesan abstrak dan memiliki konten yang kurang. Dengan kondisi demikian maka penelitian perlu dilakukan agar pembelajaran di dalam kelas menjadi lebih bermakna, menyenangkan dan mengaktifkan siswa. Media pembelajaran dirasa dapat memberikan peningkatan hasil belajar serta menumbuhkan minat siswa dalam belajar. Upaya tersebut diantaranya dengan melakukan suatu penelitian tindakan dengan mengembangkan media pembelajaran yang ada. Berdasarkan uraian di atas, maka penelitian ini bertujuan untuk meningkatkan hasil belajar tematik dengan menggunakan media ular tangga digital.

\section{METODE}

Kegiatan penelitian ini dilakukan di SD Negeri Pengadilan 2 Kota Bogor. Siswa kelas IV dijadikan sampel penelitian. Diawali bulan Maret 2020 untuk tahap prapenelitian, yang dilakukan dengan media whatsapp. Pelaksanaan penelitian dilakukan pada bulan April 2020 dengan menggunakan kelas virtual, yaitu google classroom. Penelitian ini dilakukan dengan dua siklus, melalui rancangan penelitian sebagai berikut.

Prosedur penelitian tindakan kelas dapat disusun dengan cara sebagai berikut a) menganalisis data obyektif sekolah, terutama data kegiatan pembelajaran di kelas sekaligus menemukan masalah nyata yang akan segera dipecahkan melalui tindakan reflektif; b) menyusun rencana pelaksanaan pembelajaran (RPP) sesuai dengan kurikulum yang berlaku (K-2013); c) menyusun bahan ajar sesuai dengan kurikulum yang berlaku (K-2013); d) menyusun lembar kegiatan peserta didik (LKPD); e) membuat media/alat pembelajaran; f) menyusun intsrumen penilaian perbaikan proses pembelajaran; g) menyusun lembar observasi dan rubrik penilaian; h) menyusun kisikisi dan instrumen tes (soal) aspek pengetahuan; i) menyusun lembar observasi dan rubrik penilaian aspek keterampilan; j) melaksanakan pembelajaran sesuai dengan RPP dan melakukan penilaian hasil belajar.

Teknik Pengumpulan data terdiri dari penilaian proses pelaksanaan pembelajaran dan penilaian autentik terdiri dari penilaian kompetensi sikap, observasi, pengamatan dengan menggunakan format yang berisi sejumlah indikator perilaku yang diamati, dan penilaian kompetensi pengetahuan, yaitu tes tertulis, soal-soal yang menghendaki siswa merumuskan jawabannya sendiri. Instrumen pengumpulan data 
yang digunakan bertujuan untuk memperoleh data tentang perbaikan hasil belajar. Instrumen terdiri dari soal yang akan diberikan pada akhir pembelajaran. Adapun teknik analisis data menggunakan tabel konversi dan Desain penelitian digambarkan sebagai berikut sebagai berikut.

Tabel 1. Table Konversi

\begin{tabular}{ccc}
\hline Konversi Nilai & Kategori & Interpretasi \\
\hline $81-100$ & A & Sangat baik \\
$61-80$ & B & Baik \\
$41-60$ & C & Cukup \\
$21-40$ & D & Kurang baik \\
$0-20$ & E & Sangat kurang baik \\
\hline
\end{tabular}

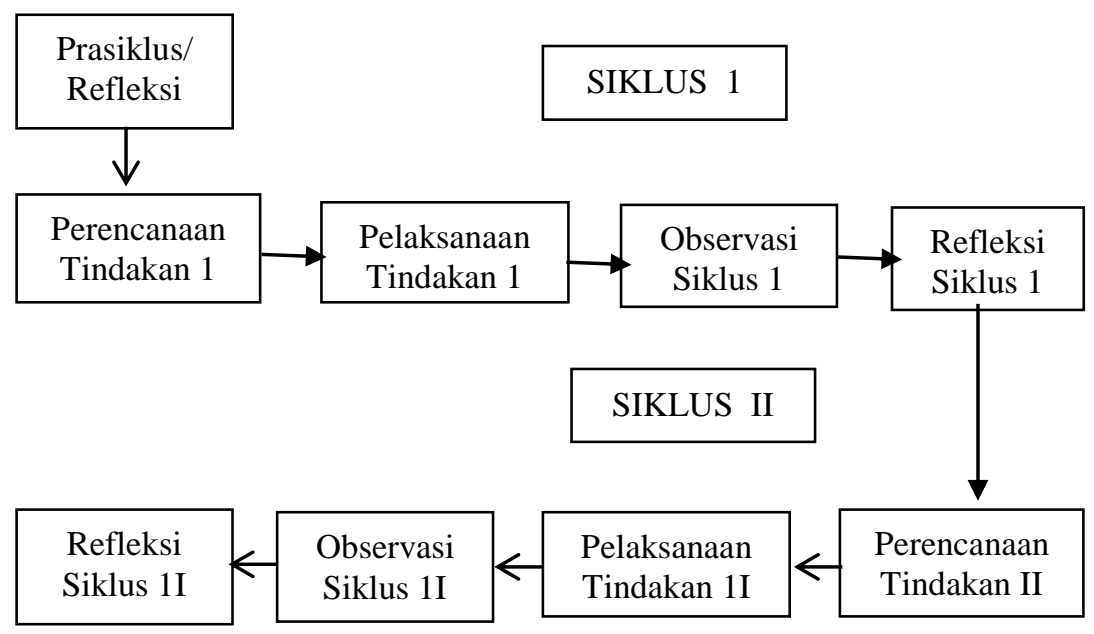

Gambar 1. Desain Penelitian Kurt Lewin (Sugiyono, 2018:34)

\section{HASIL DAN PEMBAHASAN}

Data penelitian yang diambil berupa hasil evaluasi individu, hasil observasi guru dan observasi aktivitas siswa. Observasi aktivitas siswa dan guru dilakukan dengan google classroom dan google meeting. Hal-hal tersebut dapat dijabarkan sebagai berikut.

\section{Deskripsi hasil penelitian Siklus I}

Perolehan data yang didapat dari kedua kolaborator mengenai penilaian pelaksanaan pembelajaran siklus I dapat dilihat pada tabel di bawah ini :

Tabel 2. Rekapitulasi Data Hasil Penilaian Proses Pembelajaran Siklus I

\begin{tabular}{ccc}
\hline Kolaborator & Nilai Akhir & Interpretasi \\
\hline 1 & 76 & Baik \\
2 & 77 & Baik \\
\hline Jumlah & 146 & - \\
\hline Rata-rata & 76,5 & Baik \\
\hline
\end{tabular}

Tabel di atas dapat dijelaskan pada siklus 1 proses pembelajaran dinilai baik oleh kolaborator. Proses pembelajaran masih perlu diperbaiki, terutama pada langkahlangkah pembelajaran. Pada awal pembelajaran guru masih belum menyampaikan apersepsi. Hal ini dapat dipahami, karena pembelajaran yang dilakukan dalam jaringan 
atau daring. Di mana pembelajaran dengan sistem online ini baru pertama kali dilakukan, jadi masih terkesan bingung dan kurang percaya diri. Kondisi tersebut berdampak pada kegiatan inti, menjelaskan materi pelajaran yang dilakukan guru menjadi kurang jelas. Kondisi ini dijadikan sebagai bahan refleksi dan perbaikan siklus berikutnya.

Penilaian perubahan aktivitas siswa pada saat pembelajaran merupakan hal yang diamati oleh observer ketika proses pembelajaran berlangsung. Hasil perubahan aktivitas siswa kelas IV SDN Pengadilan 2 Kota Bogor pada saat pembelajaran siklus I dapat dilihat pada tabel berikut.

Tabel 3 Rekapitulasi Data Hasil Observasi Aktivitas Siswa Siklus 1

\begin{tabular}{cccccc}
\hline \multirow{2}{*}{ Kelompok } & \multicolumn{2}{c}{ Kolaborator } & \multirow{2}{*}{ Sub Total } & Rata-Rata & Interpretasi \\
\cline { 2 - 3 } & I & II & & & \\
\hline 1 & 80 & 81 & 161 & 80,5 & Baik \\
2 & 75 & 78 & 153 & 76,5 & Baik \\
3 & 77 & 74 & 151 & 75,5 & Baik \\
4 & 76 & 78 & 154 & 77 & Baik \\
5 & 80 & 80 & 160 & 80 & Baik \\
6 & 80 & 76 & 156 & 78 & Baik \\
7 & 76 & 80 & 156 & 78 & Baik \\
8 & 80 & 80 & 160 & 80 & Baik \\
\hline Jumlah & 624 & 627 & 1251 & 625,5 & - \\
\hline Rata-Rata & 78 & 78,4 & 156,4 & 78,2 & Baik \\
\hline
\end{tabular}

Tabel 3 di atas menunjukkan bahwa kelompok 1 memperoleh nilai perubahan perilaku tertinggi dengan nilai rata-rata 80,5. Sedangkan perubahan perilaku dengan nilai terendah terdapat pada kelompok 4 dengan nilai rata-rata 75,5. Secara keseluruhan rata-rata aktivitas siswa pada siklus I dikatakan baik, dengan perolehan rata-rata 78,2 yang artinya interpretasi baik. Namun demikian masih diperlukan perbaikan dalam proses pembelajaran berikutnya agar siswa lebih berperan aktif dalam pembelajaran dan perubahan perilaku siswa semakin baik. Selanjutnya tabel di bawah merupakan data hasil belajar siswa siklus I.

Tabel 4 Rekapitulasi Data Ketuntasan Hasil Belajar Siklus I

\begin{tabular}{ccc}
\hline Keterangan & Jumlah Siswa & Presentase (\%) \\
\hline Tuntas & 24 & $68,5 \%$ \\
Belum Tuntas & 11 & $31,4 \%$ \\
Jumlah & 35 & $100 \%$ \\
\hline
\end{tabular}

Tabel 4 di atas menunjukkan ketuntasan nilai hasil belajar mata pelajaran yang dicapai siswa pada siklus I meningkat sebesar 74,20\% Sedangkan 25,80\% belum mencapai kriteria ketuntasan minimal. Rata-rata ketuntasan hasil belajar juga masih di bawah 70. Oleh karena itu perlu adanya perbaikan pada siklus II.

\section{Deskripsi Penelitian Siklus II}

Pelaksanaan penelitian siklus II, dilakukan pada hari Kamis tanggal 12 Mei 2020, melalui google classroom dan google meeting. Adapun data yang didapat dari pelaksanaan Siklus II, yaitu sebagai berikut.

Tabel 5 Rekapitulasi Data Hasil Penilaian Proses Pembelajaran Siklus II

Kolaborator Nilai Akhir Interpretasi




\begin{tabular}{ccc}
\hline I & 81,5 & Sangat Baik \\
II & 84 & Sa ngat Baik \\
\hline Jumlah & 164 & \\
Rata-rata & 82,0 & Sangat Baik \\
\hline
\end{tabular}

Hasil tabel 5 menunjukkan bahwa hasil penilaian kinerja guru pada kolaborator I yaitu yaitu 81,5 dan hasil penilaian kinerja guru pada kolaborator II yaitu 84 dengan jumlah nilai 164 pada interpretasi "Sangat Baik".

Kemudian hasil observasi aktivitas siswa secara jelasnya dapat dilihat pada tabel di bawah.

Tabel 6 Rekapitulasi Data Hasil Observasi Aktivitas Siswa Siklus II

\begin{tabular}{cccccc}
\hline \multirow{2}{*}{ Kelompok } & \multicolumn{2}{c}{ Kolaborator } & Sub Total & Rata-Rata & Interpretasi \\
\cline { 2 - 3 } & I & II & & & \\
\hline 1 & 81 & 83 & 164 & 82 & Sangat Baik \\
2 & 86 & 81 & 167 & 83,5 & Sangat Baik \\
3 & 80 & 80 & 160 & 80 & Baik \\
4 & 80 & 81 & 161 & 80,5 & Baik \\
5 & 80 & 83 & 163 & 81,5 & Sangat Baik \\
6 & 80 & 80 & 160 & 80 & Baik \\
7 & 80 & 81 & 161 & 80,5 & Baik \\
8 & 85 & 83 & 168 & 84 & Sangat Baik \\
\hline Jmlh & 652 & 651 & 1304 & 652 & \\
\hline Rata-Rata & 81,5 & 81,3 & 163 & 81,5 & Sangat Baik \\
\hline
\end{tabular}

Tabel 6 di atas menjelaskan bahwa hasil observasi perubahan perilaku siswa pada siklus II menunjukan bahwa delapan kelompok masuk ke dalam kualifikasi baik. Kelompok 1 mendapatkan perolehan nilai rata-rata 82, kelompok 2 mendapatkan perolehan nilai rata-rata 83,5, kelompok 3 mendapatkan perolehan nilai rata-rata 80 , kelompok 4 mendapatkan perolehan nilai rata-rata 80,5, kelompok 5 mendapatkan perolehan nilai rata-rata 81,5, kelompok 6 memperoleh nilai rata-rata 80, kelompok 7 memperoleh nilai rata-rata 80,5 dan kelompok 8 memperoleh nilai rata-rata 84 Secara keseluruhan, rata-rata penilaian perubahan perilaku siswa pada siklus II yaitu 81,5 dengan interpretasi sangat baik. Adapun ketercapaian nilai hasil belajar secara klasikal dari tes siklus II dapat dilihat pada tabel berikut ini.

Tabel 7 Rekapitulasi Ketuntasan Hasil Belajar Siklus II

\begin{tabular}{ccc}
\hline Keterangan & Jumlah Siswa & Presentase (\%) \\
\hline Tuntas & 31 & $88,57 \%$ \\
Belum Tuntas & 4 & $11,43 \%$ \\
\hline Jumlah & 35 & $100 \%$ \\
\hline
\end{tabular}

Data rekapitulasi pada tabel 7 menginformasikan bahwa ketuntasan hasil belajar siswa pada siklus II mengalami peningkatan dibandingkan dengan ketuntasan hasil belajar siswa pada siklus I dan telah melebihi kriteria keberhasilan penelitian yaitu terdapat 31 siswa yang sudah mencapai kriteria ketuntasan minimal (KKM) atau sebesar $88,57 \%$ tuntas, sedangkan siswa yang belum tuntas sebanyak 4 siswa atau sebesar $11,43 \%$. Nilai melebihi KKM yaitu 70. Ini menunjukkan bahwa penelitian dengan menggunakan media ular tangga digital berhasil. Detail data siklus I dan II dapat dilihat pada tabel rekapitulasi berikut.

Tabel 8 Rekapitulasi Hasl Siklus I dan II

\begin{tabular}{llll}
\hline No. & Aspek & Hasil Siklus & Keterangan \\
\hline
\end{tabular}




\begin{tabular}{|c|c|c|c|c|c|c|}
\hline & & \multicolumn{2}{|c|}{ Siklus I } & \multicolumn{2}{|c|}{ Siklus II } & \\
\hline & & Nilai & Makna & Nilai & Makna & \\
\hline 1 & Proses pembelajaran & $78,2 \%$ & Baik & $82,0 \%$ & Sangat Baik & $\begin{array}{l}\text { Meningkat } \\
3,8 \%\end{array}$ \\
\hline 2 & $\begin{array}{l}\text { Perubahan perilaku } \\
\text { /aktivitas siswa }\end{array}$ & $76,5 \%$ & Cukup & $81,5 \%$ & Baik & $\begin{array}{l}\text { Meningkat } \\
5 \%\end{array}$ \\
\hline 3 & $\begin{array}{l}\text { Ketuntasan hasil } \\
\text { pembelajaran }\end{array}$ & $68,57 \%$ & Belum & $88,57 \%$ & Berhasil & $\begin{array}{l}\text { Meningkat } \\
20 \%\end{array}$ \\
\hline 4 & $\begin{array}{l}\text { Nilai rata-rata hasil } \\
\text { belajar }\end{array}$ & 74,42 & $\begin{array}{l}\text { Belum } \\
\text { tuntas }\end{array}$ & 84,02 & Tuntas & Meningkat 9,6 \\
\hline
\end{tabular}

Tabel 8 di atas menunjukkan bahwa semua aspek yang diteliti mengalami peningkatan. Pada siklus I penilaian pelaksanaan pembelajaran mencapai nilai $78,2 \%$ dengan kategori baik, pada siklus II dilakukan perbaikan pembelajaran sehingga nilai pelaksanaan pembelajaran meningkat menjadi 82,0\% dengan kategori sangat baik. Sama halnya dengan kualitas pelaksanaan pembelajaran yang meningkat, perubahan perilaku siswa juga meningkat, perubahan perilaku siswa pada siklus I mencapai nilai $78,2 \%$ dengan interpretasi cukup baik, dan setelah dilakukan perbaikan pada siklus II maka nilai perubahan perilaku siswa meningkat menjadi $81,5 \%$ dengan interpretasi baik.

Aspek penelitian lainnya yang juga mengalami peningkatan yaitu hasil belajar siswa. Pada siklus I ketuntasan hasil belajar siswa kelas IV Sekolah Dasar Negeri Pengadilan 2 kota Bogor, secara klasikal hanya mencapai 68,57\% kemudian mengalami peningkatan $20 \%$ pada siklus II menjadi $88,57 \%$, maka penelitian selesai dilaksanakan pada siklus II karena penelitian sudah mencapai indikator keberhasilan, yaitu 75, yang artinya penelitian dengan penggunaan media ular tangga digital dikatakan berhasil. Rekapitulasi hasil penelitian siklus I dan II dapat digambarkan pada histogram di bawah ini.

\section{Rekapitulasi hasil penelitian tindakan kelas siklus I dan II}

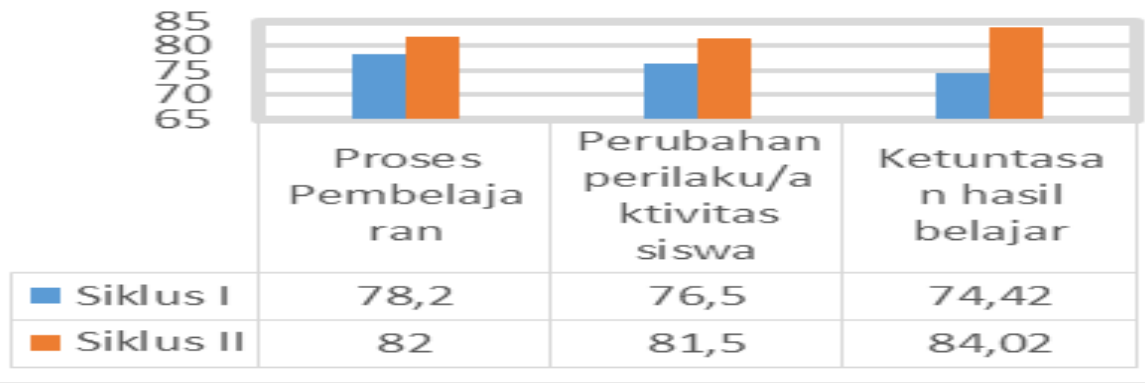

\section{Gambar 2 Histogram Penelitian Siklus 1 dan II Rekapitulasi Hasil}

Penelitian tindakan yang telah dilaksanakan dapat dijelaskan sebagai berikut.

1. Peningkatan Proses Pembelajaran

Penelitian dilakukan dengan sistem online atau dalam jaringan. Hal ini disebabkan karena pandemi covid-19. Pemanfaatan aplikasi google classroom dan google meet merupakan alternatif dalam pelaksanaan tindakan. Observasi dilakukan oleh dua orang guru sebagai kolaborator. Perolehan nilai pada pelaksanaan tindakan siklus 1 ditunjukan dengan kategori baik. Meskipun pada awal pelaksanaan pembelajaran terjadi miskomunikasi antara guru, kolaborator, dan siswa. Diskusi 
dilakukan untuk mencari solusi dalam pelaksanaan pembelajaran yang belum terbiasa ini. Kemudian pembelajaran dilakukan kembali setelah mendapatkan kesepakatan dalam penerapan metode pembelajaran. Miskomunikasi terjadi juga dalam penilaian autentik. Perolehan nilai rata-rata siklus 1 ditunjukkan pada 78,2\%. Angka tersebut dapat dikatakan ada pada kategori baik. Beberapa faktor dapat dikatakan sebagai penyebab dari perolehan nilai tersebut. Diantaranya persiapan yang masih belum maksimal dalam pembelajaran berbasis online, seperti ketersediaan internet, alat seperti handphone yang digunakan siswa, serta lokasi siswa. Kemudian kesiapan guru dalam pembelajaran, tujuan pembelajaran belum tersampaikan, guru masih minim dalam memberikan motivasi, apersepsi.

Hal ini dapat dipahami karena ketersediaan alokasi waktu yang perlu diperbaiki. Materi pembelajaran belum tersampaikan dengan baik. Perhatian atau konsentrasi siswa masih terbagi artinya masih ada siswa yang kurang memperhatikan siswa lainnya yang sedang presentasi. Kondisi ini dijadikan sebagai bahan refleksi untuk perbaikan pada pelaksanaan tindakan pada siklus II. Sebelum dilakukan perbaikan siklus II, dilakukan diskusi yang mendalam mengenai kegiatan tindakan yang perlu dilakukan. Kesiapan metode, alat komunikasi, serta jaringan internet disiapkan dengan baik, agar tidak terjadi kesalahan yang sama pada siklus sebelumnya. Koordinasi dilakukan dengan melibatkan orang tua siswa, agar siswa memiliki kesiapan dalam pelaksanaan presentasi. Koordinasi juga dilakukan bersama kolaborator. Observasi atau pengamatan yang dilakukan pada siklus II memperoleh hasil 82\%. Angka ini lebih besar dari perolehan pada siklus 1. Peningkatan ini terjadi disebabkan guru sudah memiliki kesiapan dalam pembelajaran. Koordinasi dilakukan dengan baik antara kolaborator, siswa serta keterlibatan orang tua siswa.

Penelitian tindakan kelas dapat dikatakan berhasil jika mencapai nilai rata-rata di atas indikator keberhasilan. Penggunaan media ular tangga digital ini merupakan salah satu cara dalam meningkatkan hasi belajar. Penggunaan media lain dapat dilihat pada penelitian penelitian lainnya seperti (McKenzie, 2007), (Silverman et al., 2019), (Nee \& Dozier, 2017), (Silverman et al., 2019), (Wu, 2017) dan (Silpha \& Sunita, 2016). Penelitian-penelitian tesrebut menemukan pentingnya penggunaan media bagi pembelajaran.

2. Perubahan perilaku/aktivitas siswa

Pembelajaran siklus I dilaksanakan dengan membagi kelompok siswa. Pembagian kelompok bertujuan untuk meningkatkan aktivitas serta kerjasama siswa. Diketahui rata-rata nilai perubahan perilaku atau aktivitas siswa pada siklus I, yaitu 76,5\%. Perolehan nilai pada siklus 1 ini dapat dikategorikan ada pada kategori baik. Keaktifan siswa dalam pembelajaran daring masih belum terlihat, hal ini dapat disebabkan karena siswa terkendala dengan jaringan internet. Oleh sebab itu dilakukan pembelajaran atau pelaksanaan tindakan siklus II. Peningkatan keaktifan siswa mencapai $81,5 \%$ pada siklus II. Artinya siswa juga sudah terbiasa dengan pembelajaran online menggunakan google classroom dan google meeting. Dengan media seperti game ular tangga ini, perubahan siswa dalam belajar dapat meningkat. Hal tersebut disebabkan pada tingkatan ini siswa menyenangi permainan. Sejalan dengan hal tersebut (Din \& Gibson, 2019), (Kalmpourtzis, 2018), (Zumbach et al., 2020), (Behnamnia, Kamsin, Ismail, et al., 2020), (Behnamnia, Kamsin, \& Ismail, 2020), dan (Kuncahyono \& Sudarmiatin, 2018) dapat dikatakan bahwa game berbasis multimedia interaktif merupakan media yang berpengaruh penting pada peserta didik dan dapat menarik perhatian siswa sehingga siswa lebih tertarik dalam belajar. 


\section{Ketuntasan Hasil Belajar}

Indikator keberhasilan hasil belajar siswa diperoleh minimal mencapai 75\% dari jumlah siswa yang mencapai kriteria ketuntasan (KKM). Ketuntasan hasil belajar pada siklus I mencapai angka 74,42. Nilai atau hasil siklus I belum mencapai indikator keberhasilan, sehingga perlu dilakukan siklus II. Perbaikan proses pembelajaran dilakukan untuk mencapai indikator keberhasilan. Oleh sebab itu dilakukan perbaikan pada siklus II. Pelaksanaan tindakan dilakukan oleh guru menggunakan media ular tangga digital yang sudah ada pada android. Guru menjelaskan materi dengan aplikasi google meeting, kemudian siswa diminta untuk menjawab pertanyaan yang terdapat pada permainan ular tangga. Setelah itu siswa dengan dipantau guru, mengirimkan hasil tes, dan kemudian guru memberikan peniliaian. Hasil tes didapatkan rata-rata sebesar 84,02 . Hasil rata-rata tersebut lebih besar dari indikator keberhasilan yang telah ditetapkan. Dengan demikian dapat dikatakan bahwa penelitian dengan menggunakan media ular tangga digital dinyatakan berhasil.

Berhasil atau tidaknya suatu pembelajaran tidak terlepas dari peran guru dan siswa dalam pelaksanaan pembelajaran. Guru dalam menciptakan kelas yang komunikatif salah satunya penggunaan media pembelajaran. Temuan hasi penelitian Media ular tangga digital dapat dijadikan alternatif dalam keberhasilan belajar. Terjadinya peningkatan hasil belajar disebabkan penggunaan media ular tangga digital. (Novita et al., 2019), mengemukakan temuan penelitian pentingnya pengembangan media pembelajaran berbasis teknologi. Penelitian (Nuryanti, 2017) menemukan hasil perhitungan gain score: Ular Tangga Akuntansi dapat meningkatkan motivasi belajar siswa sebesar 0,20 (nilai gain < 0,3, kategori rendah). Kemudian (Widowati, 2016) menemukan hasil penelitian yang menunjukkan adanya peningkatan hasil belajar dengan menggunakan media ular tangga berbasis teknologi Kemudian (Napitupulu \& Hardianti, 2018), menemukan hasil penelitian terdapat pengaruh penggunaan medai ular tangga berbasis macromedia flash.

Selanjutnya Haryanto dan Adiwiharja (2015) menemukan hasil penelitian bahwa media pembelajaran ular tangga yang disisipkan edukasi menjadi salah satu media yang dapat memudahkan siswa dalam memahami pelajaran yang diberikan oleh pengajar agar pembelajaran berjalan efektif yang menyenangkan serta menarik. (Guterres et al., 2018) dalam penelitiannya menemukan bahwa penggunaan media ular tangga berbasis android dapat meningkatkan hasil belajar. Pentingnya penggunaan dan pengembangan media dalam pembelajaran juga diteliti oleh (Tarng et al., 2009), (Martin et al., 2019), (Andres \& Petersen, 2002), (Martin et al., 2019).

Merujuk dari data tersebut di atas, hasil belajar dapat ditingkatkan dengan menggunakan media ular tangga digital. Media ular tangga yang berbentuk permainan ini juga memiliki manfaat dalam menumbuhkan kerjasama dengan siswa lain. Hal ini dikarenakan media ini dapat dimainkan secara berkelompok. Oleh sebab itu guru sudah selayaknya mampu menciptakan konsep-konsep baru dalam pengembangan media pembelajaran. Pembelajaran dewasa ini menuntut guru dalam penguasaan teknologi. Penciptaan dan pengembangan media baik itu yang berbasis teknologi maupun produk baru bertujuan dalam upaya menciptakan kualitas pembelajaran yang lebih baik.

\section{SIMPULAN}

Berdasarkan pembahasan hasil penelitian, dapat disimpulkan bahwa hasil belajar tematik dapat meningkat dengan adanya penggunaan media ular tangga digital. Hal ini 
dapat dilihat dari hasil penelitian mengenai, proses pembelajaran, perubahan perilaku siswa, dan hasil belajar. Proses pembelajaran siklus I nilai rata-rata yang diperoleh yaitu $78,2 \%$ dengan interpretasi baik. Kemudian pada siklus II nilai rata-rata yang diperoleh yaitu $82,0 \%$ dengan interpretasi sangat baik. Perubahan perilaku atau aktivitas siswa dengan nilai rata-rata pada siklus I yaitu sebesar 76,5\% interpretasi baik. Nilai rata-rata perubahan perilaku siswa pada siklus II sebesar $81,5 \%$ dengan interpretasi sangat baik. Ketuntasan hasil belajar siklus I diperoleh nilai rata-rata 74,42 sedangkan pada siklus II nilai rata-rata yang diperoleh siswa sebesar 84,02. dengan ketuntasan hasil belajar sebesar $88,57 \%$.

Pembelajaran aktif, inovatif, kreatif, efektif, dan menyenangkan gembira dan berbobot atau disingkat dengan PAIKEM Gembrot, akan terjadi di dalam kelas. Kondisi ini tercipta dengan kreativitas guru yang mampu mengembangkan media pembelajaran ular tangga digital ini. Pemahaman guru akan kebutuhan siswa, dapat menciptakan pembelajaran yang inovatif. Guru kreatif dapat menciptakan pembelajaran yang menyenangkan, sehingga tujuan pembelajaran yang diharapkan akan tercapai. Penggunaan media pembelajaran seperti ular tangga digital ini akan memicu semangat dan motivasi siswa dalam belajar, baik di dalam kelas maupun di luar kelas.

Dapat dikatakan bahwa selayaknya media digunakan dalam proses pembelajaran. Media pembelajaran baik itu media konvensional maupun berbasis teknologi dapat menciptakan siswa menjadi aktif dan kreatif. Diharapkan guru dapat menciptakan inovasi baru dalam media pembelajaran, sehingga pembelajaran menjadi lebih berkualitas. Pengembangan media pembelajaran dapat terus dilakukan baik oleh guru maupun oleh peneliti dalam mewujudkan tujuan pendidikan.

\section{REFERENSI}

Afandi, R. (2015). Pengembangan Media Pembelajaran Permainan Ular Tangga Untuk Meningkatkan Motivasi Belajar Siswa dan Hasil Belajar IPS di Sekolah Dasar. JINoP (Jurnal Inovasi Pembelajaran), 1(1), 77. https://doi.org/10.22219/jinop.v1i1.2450

Alial-Sahel, R. (2005). Teachers' perceptions of underachievement in elementary schools in Kuwait. School Psychology International, 26(4), 478-493. https://doi.org/10.1177/0143034305059027

Andres, H. P., \& Petersen, C. (2002). Presentation Media, Information Complexity, and Learning Outcomes. Journal of Educational Technology Systems, 30(3), 225246. https://doi.org/10.2190/3twa-nva7-0mew-402j

Bawa, P., Lee Watson, S., \& Watson, W. (2018). Motivation is a game: Massively multiplayer online games as agents of motivation in higher education. Computers and Education, 123, 174-194. https://doi.org/10.1016/j.compedu.2018.05.004

Behnamnia, N., Kamsin, A., \& Ismail, M. A. B. (2020). The landscape of research on the use of digital game-based learning apps to nurture creativity among young children: A review. Thinking Skills and Creativity, 37(May), 100666. https://doi.org/10.1016/j.tsc.2020.100666

Behnamnia, N., Kamsin, A., Ismail, M. A. B., \& Hayati, A. (2020). The effective components of creativity in digital game-based learning among young children: A case study. Children and Youth Services Review, 116(June). https://doi.org/10.1016/j.childyouth.2020.105227 
Delcourt, M. A. B., Cornell, D. G., \& Goldberg, M. D. (2007). Cognitive and affective learning outcomes of gifted elementary school students. Gifted Child Quarterly, 51(4), 359-381. https://doi.org/10.1177/0016986207306320

Dewi, T. L., Kurnia, D., \& Panjaitan, R. L. (2017). Penggunaan Media Pembelajaran PIPS untuk Meningkatkan Hasil Belajar Siswa. Jurnal Pena Ilmiah, 2(1), 20912100.

Din, Z. U., \& Gibson, G. E. (2019). Serious games for learning prevention through design concepts: An experimental study. Safety Science, 115(January), 176-187. https://doi.org/10.1016/j.ssci.2019.02.005

Efendi, N. M. (2018). Mahasiswa Ilmu Antropologi Pascasarjana UGM 173. 2(2), $173-$ 182.

Gillies, R. M., \& Ashman, A. F. (2000). The effects of cooperative learning on students with learning difficulties in the lower elementary school. Journal of Special Education, 34(1), 19-27. https://doi.org/10.1177/002246690003400102

Guterres, I. K. N. P., Sudarti, S., M, M., \& Putra, P. D. A. (2018). Pengembangan Media Pembelajaran Ular Tangga Berbasis Android Pada Pokok Bahasan Gejala Pemanasan Global Untuk Pembelajaran Fisika Di Sma. Jurnal Pembelajaran Fisika, 7(1), 54. https://doi.org/10.19184/jpf.v7i1.7225

Hidayati, N., \& Wuryandari, A. I. (2012). Media Design for Learning Indonesian in Junior High School Level. Procedia - Social and Behavioral Sciences, 67(November 2011), 490-499. https://doi.org/10.1016/j.sbspro.2012.11.354

Kalmpourtzis, G. (2018). Educational Game Design Fundamentals. In Educational Game Design Fundamentals. https://doi.org/10.1201/9781315208794

Karo-Karo, I. R., \& Rohani. (2018). Manfaat Media dalam Pembelajaran. 1, 6-8. https://doi.org/10.16309/j.cnki.issn.1007-1776.2003.03.004

Kuncahyono, K. (2018). Pengembangan E-Modul (Modul Digital) dalam Pembelajaran Tematik Di Sekolah Dasar. JMIE (Journal of Madrasah Ibtidaiyah Education), 2(2), 219-231.

Kuncahyono, K., \& Sudarmiatin, S. (2018). Pengembangan Multimedia Interaktif Pada Pembelajaran Tematik Indahnya Negeriku Untuk Siswa Kelas IV Sekolah Dasar. Ilmu Pendidikan: Jurnal Kajian Teori Dan Praktik Kependidikan, 3(2), 156-163.

Law, A. S., \& Stock, R. (2019). Learning approach and its relationship to type of media use and frequency of media-multitasking. Active Learning in Higher Education, 20(2), 127-138. https://doi.org/10.1177/1469787417735612

Martin, W., Silander, M., \& Rutter, S. (2019). Digital games as sources for science analogies: Learning about energy through play. Computers and Education, 130(March 2018), 1-12. https://doi.org/10.1016/j.compedu.2018.11.002

McKenzie, A. R. (2007). The use of learning media assessments with students who are deaf-blind. Journal of Visual Impairment and Blindness, 101(10), 587-600. https://doi.org/10.1177/0145482x0710101004

Napitupulu, S. M., \& Hardianti, T. (2018). Penggunaan Media Ular Tangga Berbasis Macromedia Flash Pada Materi Glb Dan Glbb Terhadap Hasil Belajar Siswa Di Sma Al-Washliyah Medan Use of Ladder Snake Media Based on Macromedia Flash in Glb and Glbb Materials on Results Learning. 02, 9-14.

Nee, R. C., \& Dozier, D. M. (2017). Second screen effects: Linking multiscreen media use to television engagement and incidental learning. Convergence, 23(2), 214226. https://doi.org/10.1177/1354856515592510 
Novita, L., Sukmanasa, E., \& Pratama, M. Y. (2019). Penggunaan Media Pembelajaran Video terhadap Hasil Belajar Siswa SD. Indonesian Journal of ..., 3(2), 64-72.

Novita, L., Windiyani, T., \& Fauziah, S. S. (n.d.). Analisis Pemanfaatan Media Pembelajaran Berbasis TIK Di Sekolah Dasar Negeri Pengadilan 5 Bogor.

Nuryanti, E. (2017). Pengembangan Permainan Ular Tangga, Media Pembelajaran Jurnal Khusus Untuk Meningkatkan Development of Snake and Ladder Game , a Learning Media in. 45, 1-20.

O’Connor, E. E., Dearing, E., \& Collins, B. A. (2011). Teacher-child relationship and behavior problem trajectories in elementary school. American Educational Research Journal, 48(1), 120-162. https://doi.org/10.3102/0002831210365008

Okada, Y., \& Matsuda, T. (2019). Development of a Social Skills Education Game for Elementary School Students. Simulation and Gaming, 50(5), 598-620. https://doi.org/10.1177/1046878119880228

Schneider, S., Beege, M., Nebel, S., \& Rey, G. D. (2018). A meta-analysis of how signaling affects learning with media. Educational Research Review, 23(August 2017), 1-24. https://doi.org/10.1016/j.edurev.2017.11.001

Silpha, S., \& Sunita, M. (2016). Positive Influence of the Multimedia in Primary Education. The International Journal of Indian Psychology, Vol 2(e-ISSN 23485396 p-ISSN: 2349-3429).

Silverman, R. D., Artzi, L., McNeish, D. M., Hartranft, A. M., Martin-Beltran, M., \& Peercy, M. (2019). The relationship between media type and vocabulary learning in a cross age peer-learning program for linguistically diverse elementary school students. Contemporary Educational Psychology, 56, 106116. https://doi.org/10.1016/j.cedpsych.2018.12.004

Syawaluddin, A., Afriani Rachman, S., \& Khaerunnisa. (2020). Developing Snake Ladder Game Learning Media to Increase Students' Interest and Learning Outcomes on Social Studies in Elementary School. Simulation and Gaming, 51(4), 432-442. https://doi.org/10.1177/1046878120921902

Tarng, W., Tsai, W. S., Lin, Y. S., \& Shiu, C. K. (2009). Instructional design using the virtual ecological pond for science education in elementary schools. World Academy of Science, Engineering and Technology, 37(4), 392-403. https://doi.org/10.5281/zenodo.1076544

Wang, Y., \& Lin, G. (2020). Efficient deep learning techniques for multiphase flow simulation in heterogeneous porousc media. Journal of Computational Physics, 401, 108968. https://doi.org/10.1016/j.jcp.2019.108968

Widowati, F. (2016). Penggunaan Media Ular Tangga Untuk Meningkatkan Hasil Belajar. 2(1).

$\mathrm{Wu}$, J. Y. (2017). The indirect relationship of media multitasking self-efficacy on learning performance within the personal learning environment: Implications from the mechanism of perceived attention problems and self-regulation strategies. Computers and Education, 106, 56-72. https://doi.org/10.1016/j.compedu.2016.10.010

Zumbach, J., Rammerstorfer, L., \& Deibl, I. (2020). Cognitive and metacognitive support in learning with a serious game about demographic change. Computers in Human Behavior, 103(July 2019), 120-129. https://doi.org/10.1016/j.chb.2019.09.026 